\title{
Reservoir implantation for flood dampening in the Macaé River basin using the Mohid Land model
}

\author{
Jader Lugon Junior' \\ Luiza Paula da Silva Tavares" \\ Francine de Almeida Kalas"II \\ Pedro Paulo Gomes Watts Rodrigues IV \\ Julio Cesar Alvim Wasserman ${ }^{\vee}$
}

\section{Abstract}

The use of computational models of varied complexity helps to understand the hydrological dynamics studying different scenarios of urban flood. In this perspective, a hydrological model of the Macaé river basin (RH-VIII) was built using the MOHID Land platform to simulate the implementation of a hypothetical attenuation reservoir for flood mitigation in the Macaé urban region. The results indicate that the maximum flows obtained with the simulation from project rainfalls were compatible with values observed in the literature, in the region of interest. The analysis of the flood hydrograms $(\mathrm{m} 3 / \mathrm{s})$ indicates a high efficiency in flood mitigation near the reservoir region, higher than $50 \%$, while at the lower part of the basin, more urbanized region, the attenuation was of the order of $10 \%$.

Keywords: Hydrographic basin. Mohid Land. Flood events. Macaé.

\footnotetext{
'Doutor em Modelagem Computacional, Professor do Instituto Federal Fluminense, Rio de Janeiro, RJ, Brasil, jlugonjr@gmail.com

"Mestre em Engenharia Ambiental, Programa de Pós-Graduação em Engenharia Ambiental Instituto Federal Fluminense, Rio de Janeiro, RJ, Brasil, luizaps@gmail.com

II' Doutora em Modelagem Computacional, Pesquisadora no Departamento de Modelagem Computacional Universidade do Estado do Rio de Janeiro, Rio de Janeiro, RJ, Brasil, francine_kalas@hotmail.com

^v PhD pela School of Marine Science and Techonology, Professor associado do Departamento de Modelagem Computacional Universidade do Estado do Rio de Janeiro, Rio de Janeiro, RJ, Brasil, pwatts@iprj.uerj.br

`Pós-doutor em Química Ambiental, Professor Titular da Universidade Federal Fluminense, Rio de Janeiro, RJ, Brasil, julio.wasserman@gmail.com
} 


\section{Introduction}

The intensification of the urbanization process in the last decades has provoked a series of changes in the environment. The inadequate occupation of river plains, and consequent waterproofing of river basins, has been contributing to the intensification of floods in different regions of Brazil. Although flooding processes are related to natural causes, their intensification, due to changes in the surface, the intense rainfall regime, the basin geometry, or the combination of one or more of these factors, results in negative impacts on society as a whole, the loss of human life, assets and the proliferation of disease vectors. In this sense, the problem of floods is revealed in the interface of land use planning and occupation and fluvial geomorphology, with inevitable unfolding in the management of water resources.

One of the most conspicuous ways to assess the hydrological behavior of river basins is the development and application of hydrological simulation models with the help of mapping techniques (VIOLA et al., 2009). Current models integrate the processes of hydrological and hydrodynamic models into only one tool and are often also associated with Geographic Information Systems (GIS) (TOMINAGA, 2013). GIS allows the unification of topographic information of the river basin in a digital terrain model (TDM), used as the basis for numerical simulations related to hydrological processes occurring in the river basin (TELLES, 2016).

Hydrological models are essential tools for river basin management, as well as planning actions to mitigate flood impacts. Within the computational modeling software available for hydrological modeling, there is the MOHID platform, a three-dimensional numerical modeling system developed by Instituto Superior Técnico (IST) at the MARETEC Center for Marine and Environmental Technology Research Center of the Technical University of Lisbon (UL), Portugal. MOHID Land is the executable core specifically designed to simulate the watershed and its processes, such as precipitation, infiltration, runoff and drainage phenomena (MOHID, 2016).

In addition to help the understanding of the hydrological dynamics of the water bodies under analysis, the use of computational models allows the simulation of scenarios of interest, helping the decision-making process by the managers (HORA et al., 2011; PESSANHA, 2012; LUGON JR. et al., 2017). In this perspective, the objective of the work was to construct a hydrological model of the watershed of the Macaé River, aiming to simulate scenarios of interest for the control of floods in the Macaé River basin, which is located in a region of successive flood events, with a large contingent of affected inhabitants.

\section{Flood management and application of} computer models

Urbanization is one of the anthropogenic actions that most result in environmental impacts, precisely due to the alteration of the original characteristics of the soil. The rapid growth of cities, in a disorderly way, aggravated the problems of urban floods, as urban development tended to suppress the original vegetation cover, increasing waterproofing, introducing plumbing works and interventions and occupying the riverine plains (MIGUEZ et al., 2015).

Tucci (1995) points out that flood events in urban areas occur basically due to two processes, either alone or in an integrated way:

- Flooding due to urbanization: the increase in the frequency and magnitude of floods due to the occupation of the soil with impermeable surfaces and the network of drainage channels. Additionally, urban development can produce obstructions to the drainage as embankments and bridges, inadequate drainage and obstructions to the flow along conduits and silting;

- Floods in riparian areas - natural floods affecting the population occupying the largest river bed. These floods occur mainly due to the natural process in which the river occupies its largest bed, according to extreme events, on average with a Recurrence Time of 2 years.

These processes generate impacts that heavily alter the water balance, translating into increased peak flows (Figure 1).

Figure 1 - Comparative hydrogram between an urbanized region and a non-urbanized region.

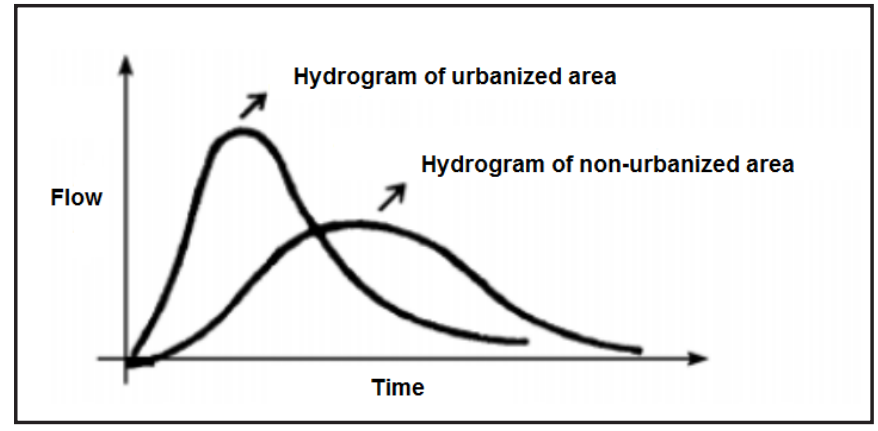

Adapted from: Tucci, 1995

The effect of different alternatives has been the target of some studies in Brazil, allied to the use of computational modeling to evaluate its effectiveness. Hydrologic models have the function of generating flood hydrograms. These hydrograms are used as input data in hydrodynamic models, capable of calculating water levels and channel flows of drainage networks. The process of using the hydrological or hydraulic model to obtain the response of the hydrographic basin and the macrodrainage network due to a set of input variables is called hydraulic-hydrological simulation. The simulation of mathematical models requires the solution of systems of equations, which demand the use of computational tools (CANHOLI, 2005). There are several software packages available for the simulation of hydrological and hydraulic models. In this work, the modeling was performed through the MOHID (Water Modeling System) computational system.

MOHID Land is a spatially distributed model for the properties of watersheds and inland drainage network. MOHID Land deals with specific processes that occur 
Figure 2 - Schematic representation of the system of equations solved by MOHID Land.

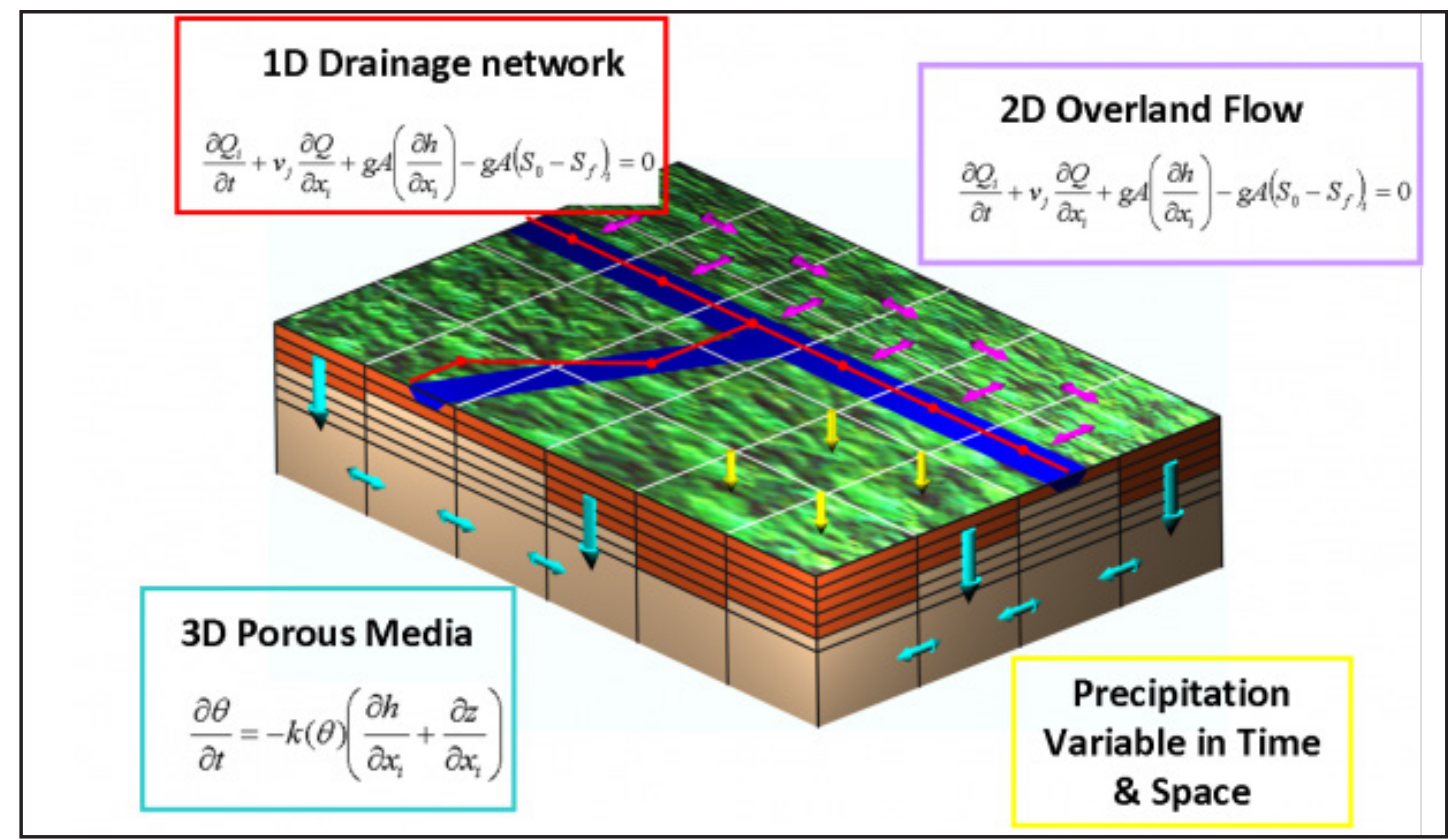

From: MOHID Wiki, 2015

in a river basin, such as: runoff, seepage and drainage network (MOHID WIKI, 2015). The system of equations solved by MOHID Land is represented Figure 2.

\section{Methodology}

\subsection{Hydrographic Region of the Macaé and Ostras Rivers}

The hydrographic region of the Macaé and Ostras Rivers (RH-VIII) is located in the southeast portion of the state of Rio de Janeiro $(\mathrm{RJ})$, between the geographical coordinates $-22^{\circ} 7^{\prime} 31^{\prime \prime}$ and $-22^{\circ} 32^{\prime} 32^{\prime \prime}$ latitudes and $-42^{\circ} 34^{\prime} 34^{\prime \prime}$ and $-40^{\circ} 38^{\prime} 35^{\prime \prime}$ longitudes. The region of study is one of the main basins of the state of Rio de Janeiro, whose drainage area presents about $2,000 \mathrm{~km}^{2}$, covering six municipalities of Rio de Janeiro (Macaé, Rio das Ostras, Nova Friburgo, Casimiro de Abreu, Carapebus and Conceição of Macabu) (FREITAS, 2015). The main river that crosses the basin, the Macaé River, is born in the mountainous region of Nova Friburgo, in Macaé de Cima, near the Tinguá peak (at $1560 \mathrm{~m}$ altitude) and flows east-southeast for about $140 \mathrm{~km}$, arriving in the Atlantic Ocean near the city of Macaé, draining an area of $1,765 \mathrm{~km}^{2}$.

The contribution of a large number of tributaries in the region of the high course significantly favors theformation of floods. The confined or partially confined riverbed also results in higher average velocities in the water course. In the lower zone of the basin there is reduction of the river slope, slowing the water velocity. As a consequence, during periods of intense rainfall, flooding of river plains occurs, where the flood wave is attenuated laterally, spreading throughout the fluvial plain, rather than downstream (SEA, 2014).

At the end of the 1960s, the Macaé River basin, along with some stretches of tributaries such as the São Pedro River, had about $60 \mathrm{~km}$ of the main canal rectilinized by the extinct National Department of Works and Sanitation (DNOS). This process brought several impacts such as silting in the terminal portion of the Macaé River, increasing the frequency and intensity of floods (FREITAS, 2015; ASSUMPÇÃO, MARÇAL, 2012).

\subsection{Mathematical and computational modeling}

The study of the hydrological behavior of the Macaé River basin and the Ostras River basin was carried out using the MOHID platform, using the MOHID Land module, a numerical tool designed to simulate hydrodynamic phenomena in river basins. The implementation of the model was carried out after the creation of a hydrological simulation project of flooding of a permeable basin. The main steps contemplated in this process are described below.

\subsubsection{Definition of the region in the GIS interface of MOHID software}

The definition of the hydrographic region of the Macaé river in the GIS interface of the MOHID was carried out with the direct importation of the map of the locality in the simulator itself. For this purpose, it was necessary to identify the estuary exudation along the estuarine region

as well as the Macaé River spring, in the upper part of the basin, in Nova Friburgo (Figure 3).

\subsubsection{Creation of the Digital Terrain Model (DTM) and delineation of the drainage network}


Figure 3 - Location of the region of interest in the MOHID Studio GIS interface

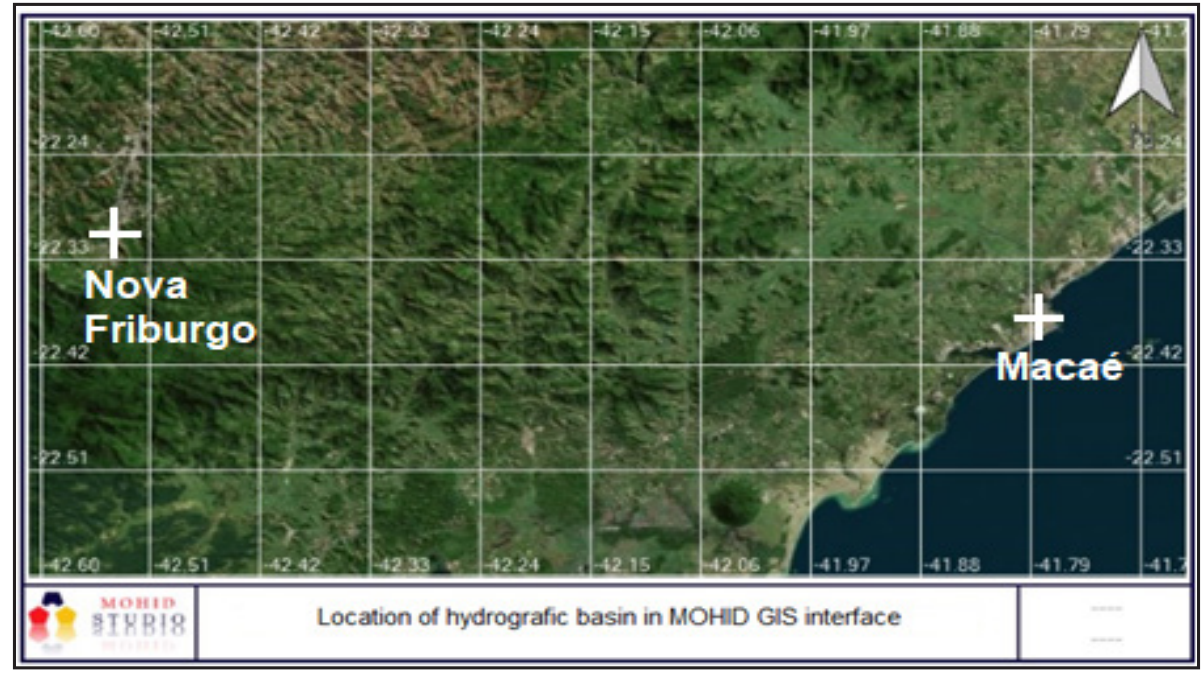

The DTM is a mathematical representation of the spatial distribution of the characteristic of a phenomenon linked to a real surface. The DTM of the Macaé river basins was created from a horizontal grid of quadratic cells of $250 \mathrm{~m}$. After defining the cell size specifications, the grid was designed over the area of interest.

The altimetric information of the terrain was obtained through the TOPODATA dataset. The Topodata project, from the Brazilian Institute of Space Research (INPE), offers a Digital Elevation Model (DEM) based on SRTM (Shutter Radar Topography Mission) data refined to a $30 \mathrm{~m}$ resolution (VALERIANO, 2005). To make the topographic files of the grid appropriate to the MOHID Land, it is necessary to remove the depressions, which allows the digital terrain to resemble the physical environment, as well as decreases the risks of emergence or disappearance of channels in the drainage network (TELLES et al., 2012; 2016).

After the construction of a consistent hydrological DTM (Digital Terrain Model), the coordinates of the hy- drographic basin outlet point is informed to the simulator. In this step, MOHID automatically delimits the drainage network. Figure 4 shows the delimitation of the DTM and drainage network of the Macaé river obtained in the GIS interface of the MOHID Land simulator.

\subsubsection{Modeling of leakage and infiltration process}

The flow and infiltration processes were modeled in the MOHID platform according to the Curve Number (CN) method, which considers the different types of soil and vegetation in a region. The value of $\mathrm{CN}$ varies from 0 to 100 according to the permeability of the river basin, being equal to 100 in completely impermeable areas.

For the Macaé River Basin, CN data were entered into the model through the MOHID Land Porous Media file, according to data reported by Sartori et al. (2005) and Sartori (2010). The elaborated CN map by MOHID Land for the Macaé river basin is shown in Figure 5..

Figure 4 - Delimitation of the catchment area of the Macaé River and its drainage network in the MOHID Land simulator

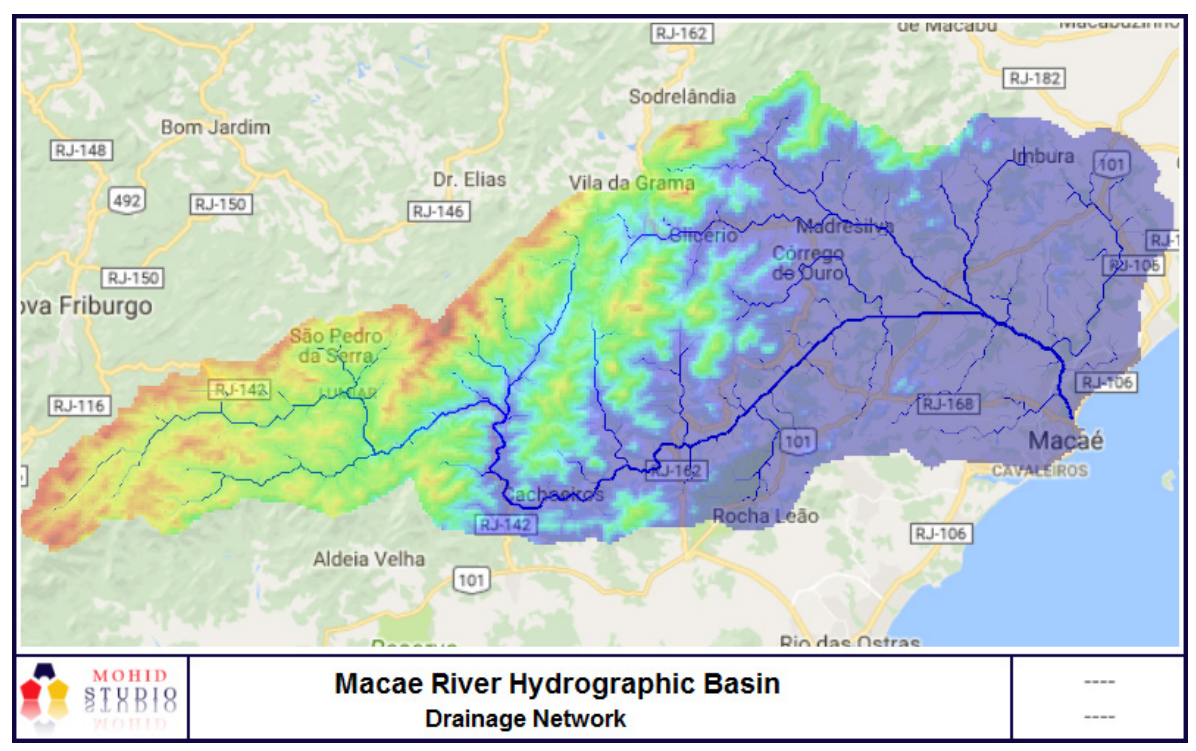


Figure 5 - Soil typology generated by the MOHID according to the $\mathrm{CN}$ values of the Macaé river basin

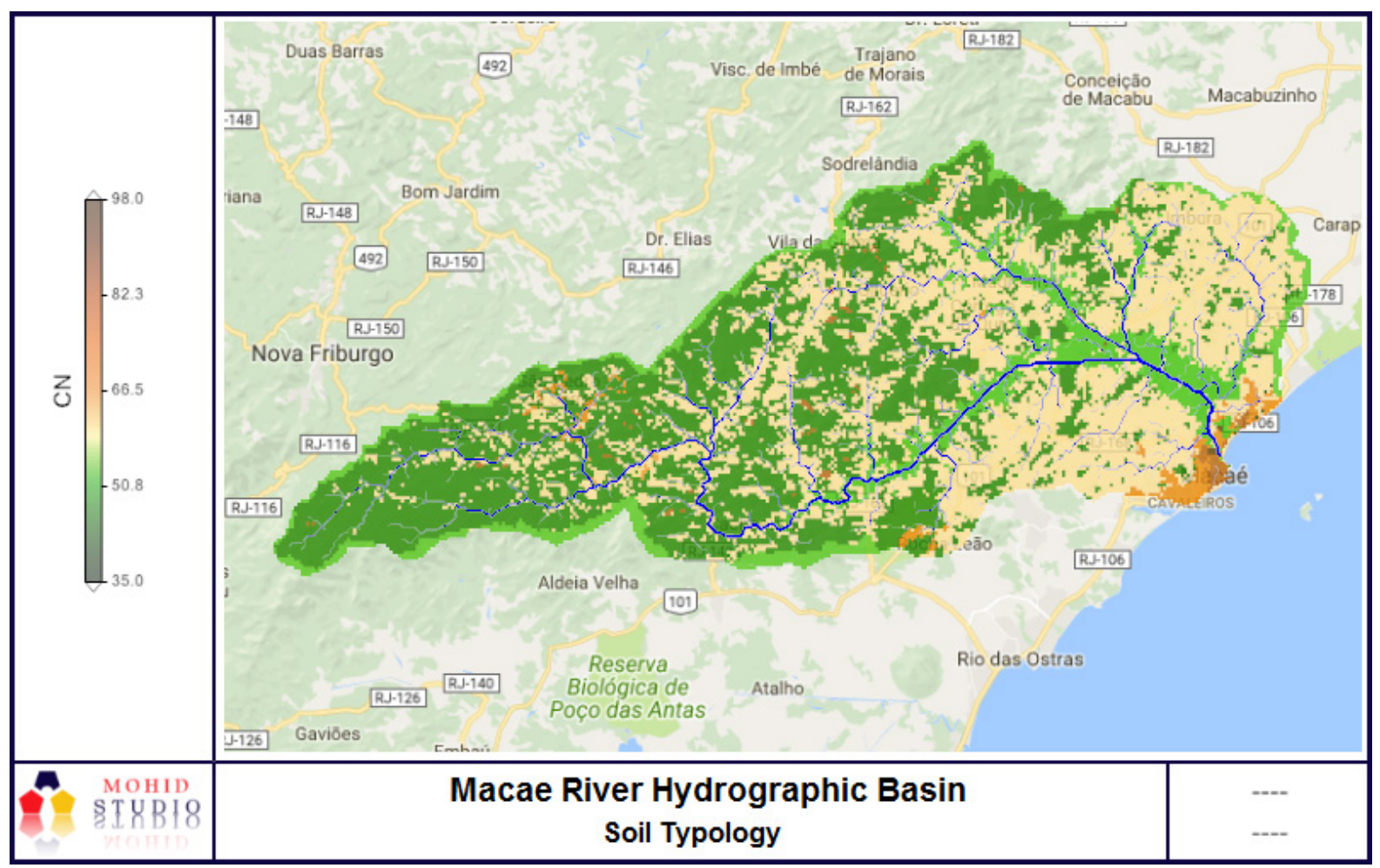

\subsubsection{Calculation of project rain}

The design rainfalls are simplified representation methodologies for the temporal distribution of precipitation, basically used as input to rainfall-flow simulation models for designing hydraulic structures (BEMFICA et al., 2000).

One of the most commonly used tools for determining the project rains is the Intensity-Duration-Frequency curves (IDF), which adopts standardized curves constructed from historical precipitation records and which have a rainfall value in relation to its total duration and its frequency, expressed in years, called the Recurrence Time (RT) (CANHOLI, 2005).

The project rains were obtained for rains lasting 24 hours or more (RIO DE JANEIRO-DER, 1989), in order to represent the same order of magnitude of the time of concentration $\left(t_{c}\right)$ of the hydrographic basin. The calculation of the concentration time considers the geomorphological parameters of a given region, and is obtained according to the following formulation (Eq. 1).

$$
t_{c}=\frac{16 L}{(1,05-0,2 p)(100 I)^{0,004}}
$$

where $t_{c}$ is the basin concentration time (minutes); $L$ is the length of the main watercourse $(\mathrm{km}) ; I$ is the slope of the region $(\mathrm{m} / \mathrm{m})$ and $p$ is the percentage of basin area covered by vegetation.

After defining the total rainfall duration (ie the concentration time established for the basin) and its Recurrence Time, the average intensities for the various durations up to the total duration are calculated based on the IDF ratios. The increments between one accumulated value and another are calculated and rearranged, so that the highest value is located at the center of the total rainfall duration, and the others are arranged in descending order, always one to the right and one to the left of the central block, alternately. This method of rearrangement is proposed by SCS (1985).

The simulation of the maximum flows in the Macaé River basin was performed from the calculation of the IDF curves proposed by Pruski et al. (2006) for the municipality of Macaé / RJ (Eq. 2). The input data for the rain-flow model are listed in Table 1, below.

$$
P=\frac{a T^{b}}{(60 t+c)^{d}}
$$

where $a, b, c, d$ are characteristics coefficients of the region; $t$ is the time duration of the rain (in hours); $T$ is the recurrence time (years) and $\mathrm{P}$ is the precipitation intensity $(\mathrm{mm} / \mathrm{h})$.

Table 1 - Model input data

\begin{tabular}{lcc}
\hline \multicolumn{1}{c}{ Parameters } & Symbols & Values \\
\hline Drainage area $\left(\mathrm{Km}^{2}\right)$ & $\mathrm{A}$ & 1765 \\
Main river length $(\mathrm{Km})$ & $\mathrm{L}$ & 147 \\
Basin concentration time (hours) & $\mathrm{t}_{\mathrm{c}}$ & 45 \\
Recurrence Time (years) & $\mathrm{RT}$ & 20 e 50 \\
Declivity $(\mathrm{m} / \mathrm{m})$ & $\mathrm{I}$ & 0,005 \\
Vegetation $(\%)$ & $\mathrm{P}$ & 71 \\
Average $\mathrm{CN}$ & --- & 54 \\
\hline
\end{tabular}


Table 2 - Manning roughness coefficients for different types of soil

\begin{tabular}{cl}
\hline Land Use Types (IBGE, 2012; 2013) & Manning roughness coefficient (n) \\
\hline Rock outcrop & 0.045 \\
Water & 0.035 \\
Wet area / Field & 0.040 \\
Wet Field & 0.050 \\
Sandy cord & 0.025 \\
Seasonal Semideciduous Lowland Forest & 0.100 \\
Submontane Semidecidual Seasonal Forest & 0.080 \\
Dense Ombrophylous Forest High Montana & 0.160 \\
Dense Ombrophylous Forest Montana & 0.160 \\
Dense Ombrophylous Forest Submontana & 0.160 \\
Dense Ombrophylous Forest Lowlands & 0.180 \\
Ombrophilous Forest and Submontana Pioneer & 0.150 \\
Formations & 0.010 \\
Mangrove & 0.040 \\
Anthropogenic Occupation & 0.060 \\
Restinga &
\end{tabular}

\subsubsection{Adjusting the roughness coefficients}

The Manning roughness coefficient is one of the main parameters for describing the flow rate on a surface. Due to the simplicity of its form and the satisfactory results in practical applications, especially from the numerous experiments developed in rivers, Manning's equation eventually acquired a more widespread use, being intensively adopted in the hydrological modeling of watercourses (LYRA et al., 2010).

One of the difficulties of applying Manning's equation is in the definition of the coefficient value for rivers or channels (CHOW, 1982; BAPTISTA, COELHO, 2010). In this work the value of 0.035 for the roughness coefficient in rivers and canals, adjusted according to the methodology proposed by Chow (1959) was adopted. Adjustments for flood plains and other areas of the basin were carried out according to information provided by INEA and according to the descriptions of types of land use reported in the literature (SEA, 2013; 2014). The chosen values for each category are listed in Table 2.

\subsubsection{Simulation Scenarios}

In the simulation process of flood control interventions in the Macaé river basin, two scenarios of interest were considered: 1) current situation of the river basin; and 2) installation of a reservoir dam in the region called "Ponte do Baião".

Scenario 1 - Current basin situation

In the previous subsections, the methodological outline for the modeling of the current situation of the Macaé River basin was presented, that is, without the existence of an intervention in the control of floods in the region. The results from the modeling of this original situation will be compared with the results from the inclusion of a reservoir in the intermediate region of the basin, in order to assess the efficiency of this type of intervention in the control of floods in this locality as well as in the lower portion of the basin, characteristically more urbanized and impacted by extreme events.

Scenario 2 - Implantation of a reservoir dam in the intermediate region of the basin

Flood containment dams are structures designed to allow the temporary retention of an expressive portion of precipitated volumes and superficially drained volumes in larger floods, thus relieving downstream stretches (FGV, 2004). Thus, the inclusion and simulation of a dam in the intermediate region of the hydrographic basin (Figure 6) allows evaluating the impacts resulting from rainfall maximum in its lower and more urbanized course.

The simulation of the dam, or reservoir, is performed in a specific MOHID Land module, which receives the flow information from the drainage network. In this module, called "Reservoirs", the outflows are calculated based on the reservoir volume and maximum flows. The data provided to the model, related to the operation of the reservoir at "Ponte do Baião", were obtained in a report about the floods in the lower Macaé River course (FGV, 2004). 
Figure 6 - Location of the simulation region of the flood containment dam, "Ponte do Baião"

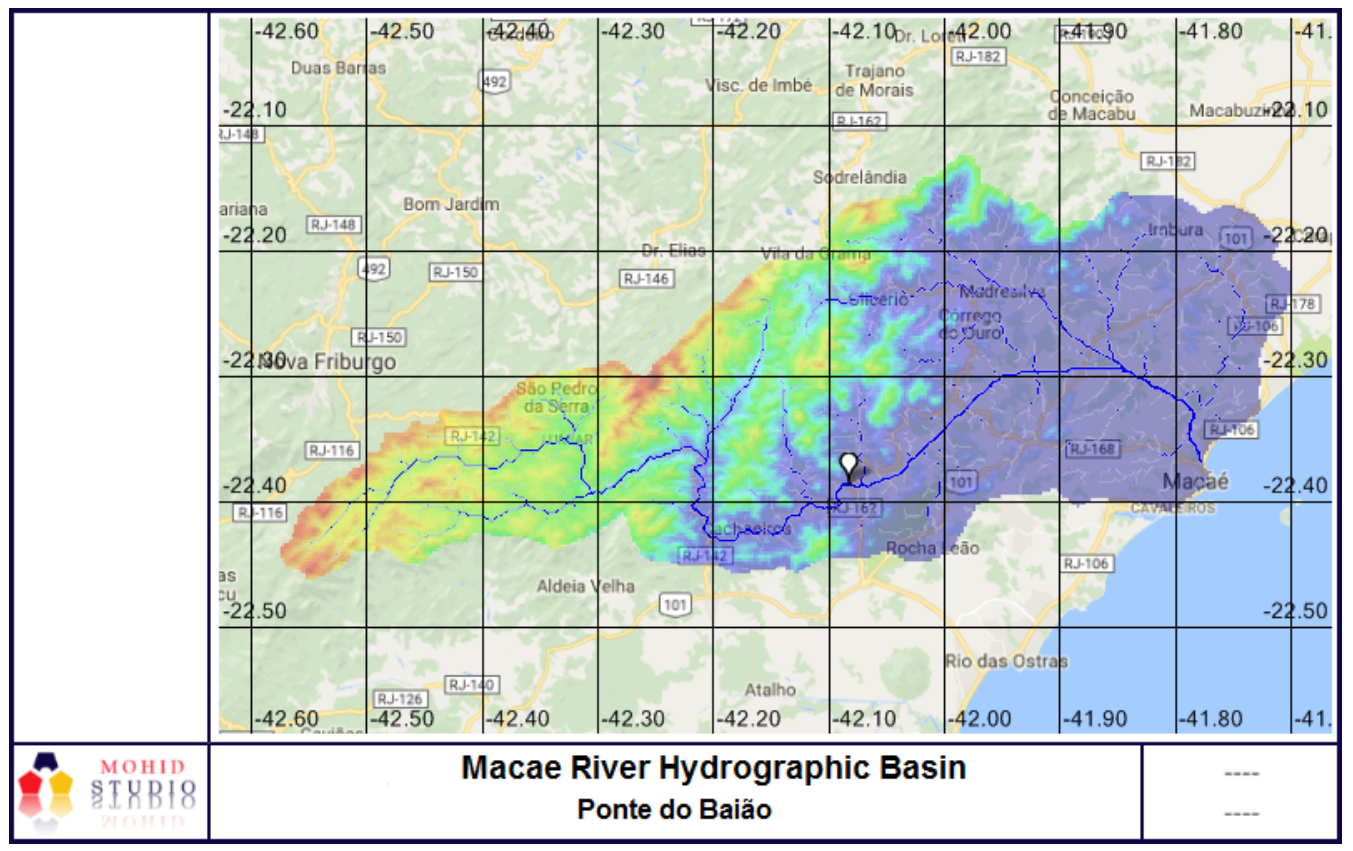

\section{Results and Discussion}

The results obtained in the simulation of the maximum flows with the use of MOHID Land in the localities of the "Ponte do Baião" and mouth of the Macaé river are summarized in Table 3, below. These results were compared to those obtained by Barboza (2014), using the rectangular unit hydrograph (HUT) method and the values presented in the water resources plan $(\mathrm{RH})$ of the SEA $(2013,2014)$ for the region.

Table 3 - Results of maximum flow $\left(\mathrm{m}^{3} / \mathrm{s}\right)$ obtained for the locations of "Ponte do Baião" and "Foz do Rio Macaé"

\begin{tabular}{cccc}
\hline Location & $\begin{array}{c}\text { MOHID Land } \\
\text { (This work) }\end{array}$ & $\begin{array}{c}\text { HUT } \\
\text { (BARBOZA, } \\
\text { 2014) }\end{array}$ & $\begin{array}{c}\text { Plano RH } \\
\text { (INEA, 2013) }\end{array}$ \\
\hline $\begin{array}{c}\text { Ponte do Baião } \\
\text { RT=20 years }\end{array}$ & 450 & 439 & 560 \\
$\begin{array}{c}\text { Ponte do Baião } \\
\text { RT=50 years }\end{array}$ & 688 & 682 & 665 \\
$\begin{array}{c}\text { Foz do Rio Macaé } \\
\text { RT =20 years }\end{array}$ & 649 & 716 & 791 \\
$\begin{array}{c}\text { Foz do Rio Macaé } \\
\text { RT }=50 \text { years }\end{array}$ & 987 & 1018 & 932 \\
\hline
\end{tabular}

It is noteworthy to observe that the flows simulated by MOHID, based on the project rains inserted into the model, show strong proximity to the values obtained by Barboza (2014) in the same region. The observed deviations for 20 and 50 years are of the order of $2.4 \%$ and $0.8 \%$, respectively, for the "Ponte do Baião" and of the order of $10 \%$ and $3 \%$, respectively, at the mouth of the Rio
Macaé. In relation to INEA data, deviations increased substantially to $24 \%$ and $3.3 \%$, respectively, for 20 and 50 years at "Ponte do Baião" and 22\% and 5.5\%, respectively, for the "Foz do Rio Macaé". Possibly, the increase in the discrepancy between the results obtained in this study and those achieved in the RH Plan may originate from the area considered in the Plan, restricted to the upper part of the Macaé River basin, which affects the final flow in the region as a whole.

The results obtained in the simulation of the hydrological behavior of the Macaé River basin, considering the two scenarios of intervention in flood control in the region, are presented below. The hydrographs obtained with the simulation considering the implantation of the reservoir show that the attenuation of the flood peaks is significant for both Recurrence Times considered in this locality (Figure 7).

The attenuation of the flood waves, with the introduction of the reservoir, reaches values superior to $50 \%$, for both Recurrence Times considered for the hydrographic basin. These results attest to the efficiency of a reservoir in the region for the control of floods from the upper and middle courses of the Macaé River, as already verified in the study of floods in the low course of the Macaé River, conducted by FGV (2004). The observed values are also consistent with the purpose of supply for this hypothetical reservoir.

Regarding the river discharge in the urban area of the city, measured at the mouth of the Macaé River, however, the results did not show a remarkable efficiency in flow reduction and flood control (Figure 8). In this locality, the attenuation of the flood waves was of the order of 5 to $15 \%$. This can be related to the distance from the mouth to the location of the dam, as well as the strong contribution coming from the confluence of the São Pedro River, as stated in the FGV report (2004). 
Figure 7 -Results obtained of maximum flow $\left(\mathrm{m}^{3} / \mathrm{s}\right)$ obtained with the simulation of scenario 1 , at "Ponte do Baião"

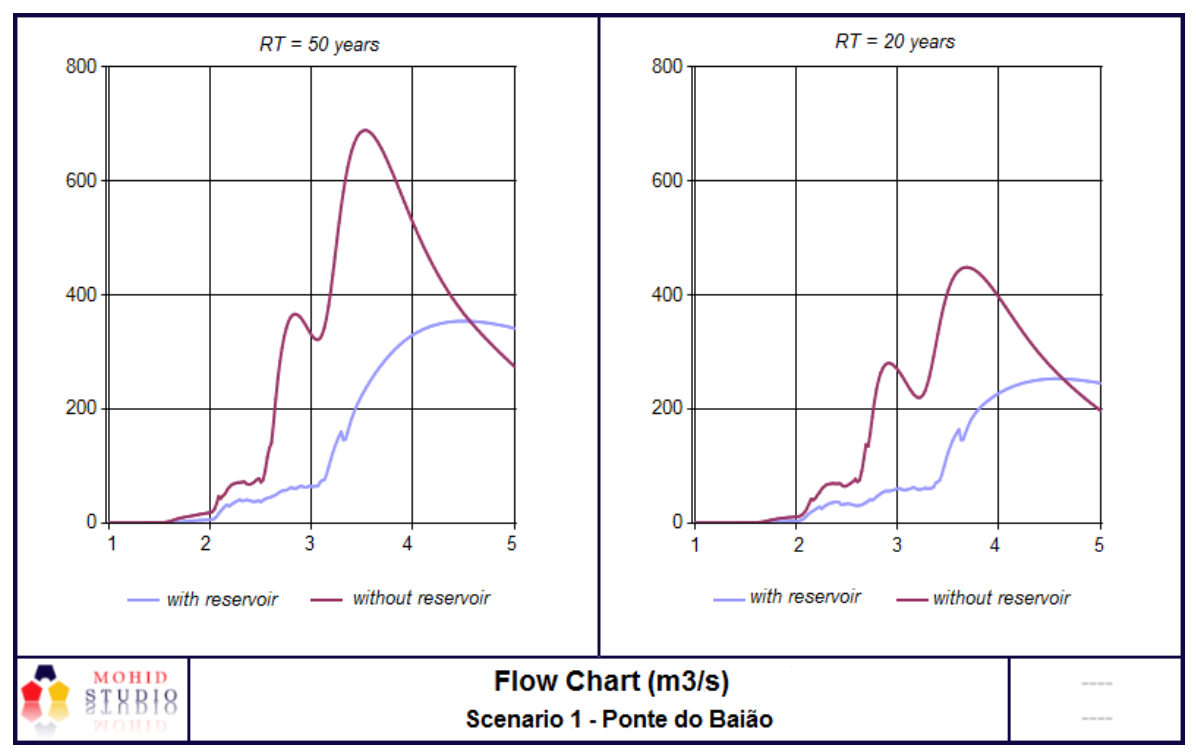

Figure 8 - Results obtained from maximum flow $\left(\mathrm{m}^{3} / \mathrm{s}\right)$ obtained with the simulation of scenario 1 , at the "Foz do Rio Macaé"

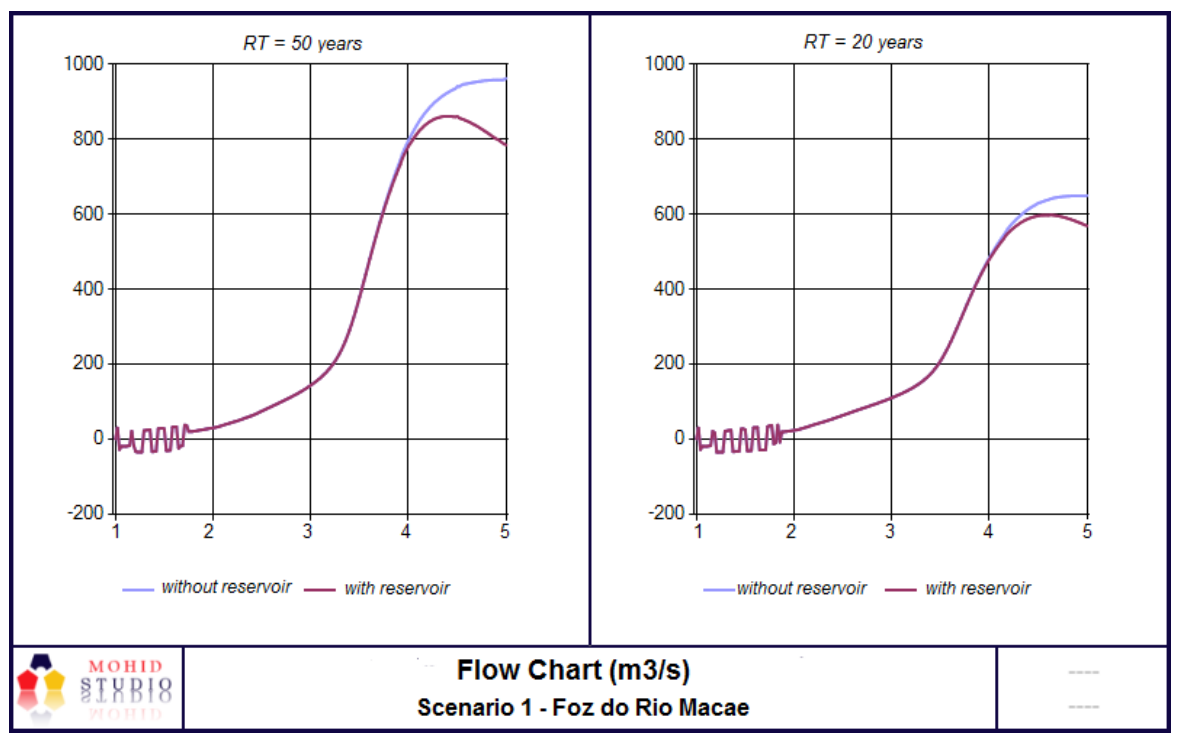

\section{Conclusions}

Urban floods are one of the most widespread and severe natural disasters in the country. The state of Rio de Janeiro has 56 official records of exceptional floods characterized as a disaster, counted between 1991 and 2012. The municipality of Macaé has a recurrent flood register with a large number of inhabitants involved.

The work focused on flood control and mitigation proposals for the Macaé region, however, are scarce and disregard the current practices evidenced in the literature. Future flood-focused studies in the region should assess the effects of new practices on urban drainage under flood in the municipality of Macaé. In the comparative analyzes for the selection of the most adequate alternative, it is necessary to consider, in addition to economically quantifiable aspects, the other aspects involved, mainly environmental, political-institutional and operational.

The results obtained for the simulation of a hypothetical implantation of a reservoir in the intermediate region of the Macaé River basin are considered satisfactory to control of the floods of the region, although its efficiency in the attenuation of river discharge in vicinity of the city of Macaé, the most urbanized region of the basin, presents values of the order of $10 \%$ only. The simulation of new scenarios, such as the installation of a dam in the contribution area of the São Pedro river or the calibration of the basin roughness coefficient, are promising alternatives for increasing the flood mitigation efficiency in the lower part of the basin. 


\section{References}

ASSUMPÇÃO AP, MARÇAL MS. Retificação dos canais fluviais e mudanças geomorfológicas na planície do Rio Macaé. Revista de Geografia. 2012;29(3):19-36 p. https://periodicos.ufpe.br/revistas/revistageografia/article/ view/228972/23381

BARBOZA AP. Estudo Hidrológico de Vazões Máximas da Bacia Hidrográfica do Rio Macaé [monography]. Rio de Janeiro: Engenharia Ambiental/UFRJ; 2014.

BAPTISTA M, COELHO MMLP. Escoamento uniforme. In: UFMG ed. Fundamentos de Engenharia Hidráulica. Belo Horizonte: UFMG, 2014. p. 225-248.

BEMFICA DC., GOLDENFUM JA., SILVEIRA AL. Análise da aplicabilidade de padrões de chuva de projeto a Porto Alegre. Revista Brasileira de Recursos Hídricos. 2000;5(4):5-16 p. DOI: https://doi.org/10.21168/rbrh.v5n4. p5-16.

CANHOLI AP. Drenagem urbana e controle de enchentes. 2st ed. São Paulo: Oficina de Textos. 2005.

CHOW VT. Open channel hydraulics. McGraw-Hill. 1982

FGV - FUNDAÇÃO GETULIO VARGAS. Estudo de cheias no baixo curso do rio Macaé, em especial sobre o núcleo urbano [report]. Rio de Janeiro, 2004.

FREITAS LE. Atlas Ambiental da Bacia Hidrográfica do Rio Macaé. 1st ed. Rio de Janeiro: Editora Nova Tríade do Brasil Ltda., 2015.

HORA HMC, TAVARES JHS, SOUZA GL, LUGON JR. J, FERREIRA, M.I.P. Modelagem computacional como ferramenta de gerenciamento dos recursos hídricos: uma alternativa para abordagem de problemas de usos múltiplos. Boletim do Observatório Ambiental Alberto Ribeiro Lamego.2011;5(1):71-87 p. DOI: https://doi. org/10.19180/2177-4560.20110004.

IBGE - INSTITUTO BRASILEIRO DE GEOGRAFIA E ESTATÍSTICA. Diretoria de Geociências. Manual Técnico da Vegetação Brasileira. In: Manuais Técnicos em Geociências (1). Rio de Janeiro, 2012.

IBGE - INSTITUTO BRASILEIRO DE GEOGRAFIA E ESTATÍSTICA. Diretoria de Geociências. Manual Técnico de Uso da Terra. In: Manuais Técnicos em Geociências(7). Rio de Janeiro, 2013.

LYRA GB, CECILIO RA, ZANETTI SS, LYRA GB. Coeficiente de rugosidade de Manning para o rio Paracatu. Revista Brasileira de Engenharia Agrícola e Ambiental, 2010;14(4):343-350 p.
LUGON JR. J, TAVARES LPS. COSTA JB, KALAS FA. Modelagem hidrológica da bacia hidrográfica do Rio Macaé utilizando o MOHID Land. Boletim do Observatório Ambiental Alberto Ribeiro Lamego, 2017;11(1):169-181 p. DOI: https://doi.org/10.19180/2177-4560.v11n12017p169-181.

MARÇAL M. Análise das mudanças morfológicas em seções transversais ao Rio Macaé/RJ. Revista Brasileira de Geomorfologia, 2013;14(1):59-68 p. DOI: http://dx.doi. org/10.20502/rbg.v14i1.365.

MIGUEZ MG, VERÓL AP., REZENDE OM. Drenagem Urbana: do projeto tradicional à sustentabilidade. 1 st ed. Rio de Janeiro: Elsevier. 2015.

MOHID Modelling Water Resources [Internet]. What is MOHID? [cited 2016 sept 14]. Available from http://www. mohid.com/pages/home/whatismohid.shtml.

MOHID WIKI [Internet]. MOHID Land [cited 2015 nov 01]. Available from https://pt.wikipedia.org/wiki/MOHID_LAND.

PESSANHA CMD. Modelagem computacional aplicada à gestão sanitário-ambiental da lagoa Imboassica-RJ [dissertation]. Macaé: Pós Graduação em Engenharia Ambiental/IFFMacaé; 2012. 67 p.

PRUSKI FF, TEIXEIRAAF, SILVA DD, CECILIO RA, SILVA JMA. Plúvio 2.1:chuvas intensas para o Brasil. In: PRUSKI FF, SILVA DD, TEIXEIRA AF, CECILIO RA, SILVA JMA, GRIEBELER N. (Org). HIDROS: dimensionamento de sistemas hidroagrícolas. Viçosa:UFV, 2006. 15-25 p.

RIO DE JANEIRO-DER, Departamento de Estradas de Rodagem. Estudo de chuvas do estado do Rio de Janeiro. Rio de Janeiro: DER, 1989. 61 p.

SARTORI A. Desenvolvimento de critérios para classificação hidrológica de solos e determinação de valores de referência para o parâmetro $\mathrm{CN}$ [thesis]. Campinas: Faculdade de Engenharia Civil, Arquitetura e Urbanismo/UNICAMP. 2010. 237 p.

SARTORI A, NETO FA, GENOVEZ AM. Classificação hidrológica de solos brasileiros para a estimativa da chuva excedente com o método do serviço de conservação do solo dos Estados Unidos Parte 1: Classificação. Revista Brasileira de Recursos Hídricos, 2005;10(4):05-18 p. https://www.abrh. org.br/SGCv3/index.php?PUB=1\&ID=26\&SUMARIO=442.

SEA - SECRETARIA ESTADUAL DO MEIO AMBIENTE. Relatório de gestão de recursos hídricos (revisão 3). In: Elaboração do plano estadual de recursos hídricos do estado do Rio de Janeiro. Rio de Janeiro, 2013.

SEA - SECRETARIA ESTADUAL DO MEIO AMBIENTE. Plano de recursos hídricos da região hidrográfica de Macaé e das Ostras: Relatório de síntese. Rio de Janeiro, 2014. http://cbhmacae.eco.br/site/wp-content/uploads/2015/06/ Relatorio_de_Situacao_ANO_II_2013-2014.pdf. 
SCS - SOIL CONSERVATION SERVICE. National engineering handbook. EUA: U.S. Department of Agriculture. 1985.

TELLES WR, SILVA NETO AJ, RODRIGUES PPGW. Avaliação do sistema de modelagem MOHID na delimitação de bacias hidrográficas. Anais do Congresso de Modelagem Aplicada e Computacional. 2012.

TELLES WR, RODRIGUES PPGW, SILVA NETO AJ. Calibração automática de um simulador aplicado a um rio de montanha empregando dados experimentais de precipitação e nível. Estudo de Caso: Córrego Dantas, RJ. Revista Brasileira de Recursos Hídricos, 2016;21(1):143-151 p. DOI: http:// dx.doi.org/10.21168/rbrh.v21n1.p143-151.

TOMINAGA ENS. Urbanização e cheias: medidas de controle na fonte [dissertation]. São Paulo: Departamento de Engenharia Hidráulica e Ambiental/USP, 2013. 137 p

TUCCI CEM. Inundações urbanas. In: TUCCI, E.M., PORTO, R.L.L., BARROS, M.T. (Org.). Drenagem urbana. UFRGS Ed. ABRH, 1995(1):15-36 p.

VALERIANO MM. Modelo digital de variáveis morfométricas com dados SRTM para o território nacional: o projeto TOPODATA. In: Anais do XII Simpósio Brasileiro de Sensoriamento Remoto; 2005 Abr 16-21, Goiana. INPE. p. 1-8.

VIOLA MR, MELLO CR, ACERBI JRFW, SILVAAM. Modelagem hidrológica na bacia Aiuruoca, MG. Revista Brasileira de Engenharia Agrícola e Ambiental, 2009;13(5):581-590 p. 